\title{
Tourism, accommodation, and the regional economy in Indonesia's West Papua
}

\author{
Oscar Tiku \\ Department of Tourism Science, Graduate School of Urban Environmental Sciences, \\ Tokyo Metropolitan University, Japan \\ oscartiku@gmail.com (corresponding author)
}

\author{
Tetsuo Shimizu \\ Department of Tourism Science, Faculty of Urban Environmental Sciences, \\ Tokyo Metropolitan University, Japan \\ t-sim@tmu.ac.jp
}

\begin{abstract}
This study deals with the contribution of visitor expenditure on West Papua's regional economy. It accomplishes three objectives: (1) to estimate the economic contribution of domestic and inbound visitor expenditure; (2) to measure the economic contribution of tourist spending at various accommodation classes; and (3) to describe the use of local commodities and labor in the regional accommodation industry. To accomplish the first and second objectives, an input-output multiplier analysis was employed. As for the third objective, interviews were conducted with 35 representatives from regional accommodation establishments. Tourism is found to contribute greatly to the regional economy, as shown from the higher overall output multiplier for tourist expenditure as compared to the regional output multiplier. The output multiplier for inbound tourist expenditure is higher than the domestic tourist. Three-star accommodations are found to be the biggest contributor with outstanding inter-sectoral impact on fisheries; food, beverage, and tobacco manufacture; and agriculture. The qualitative analysis suggests the existence of a large leakage $( \pm 90 \%)$, mainly in produce and chemicals used in daily operations. Fisheries and wood furniture are the exception. Overall, the accommodation sector absorbs a considerable extent of local labor (73\%), 23\% of which are Indigenous Papuans.
\end{abstract}

Keywords: accommodation, Indigenous Papuan, islands, multiplier analysis, Papua Barat, regional economy, tourism, West Papua

https://doi.org/10.24043/isj.124 • Received February 2020, accepted June 2020

(C) 2020-Institute of Island Studies, University of Prince Edward Island, Canada.

\section{Introduction}

Papua Barat (West Papua) is one of the two provinces in the easternmost territory of Indonesia. Geographically, it lies on the westernmost tip of the world's second-largest island, 
New Guinea (UNEP, 1998), next to Papua Province of Indonesia, which borders the nation of Papua New Guinea on its eastern side (see Figure 1).

In March 2019, West Papua was declared as Indonesia's and world's first conservation province that includes Bird's Head Seascape, a crucial part of the Coral Triangle that covers the richest marine biodiversity territory in the world (Conservation International, n.d.). With Manokwari Regency as the provincial capital, the province, which was formerly known as Irian Jaya Barat and has been acknowledged as a special autonomous province since 2004, has a city and twelve regencies in its territory. Based on the number of islands, West Papua is known as Indonesia's largest archipelagic province. It comprises 4,108 islands, with a total area of 102,955.15 $\mathrm{km}^{2}$ (BPS-Statistics Indonesia, 2017) and has an estimated population of 915,400 people (BPS-Statistics of Papua Barat Province, 2018b).

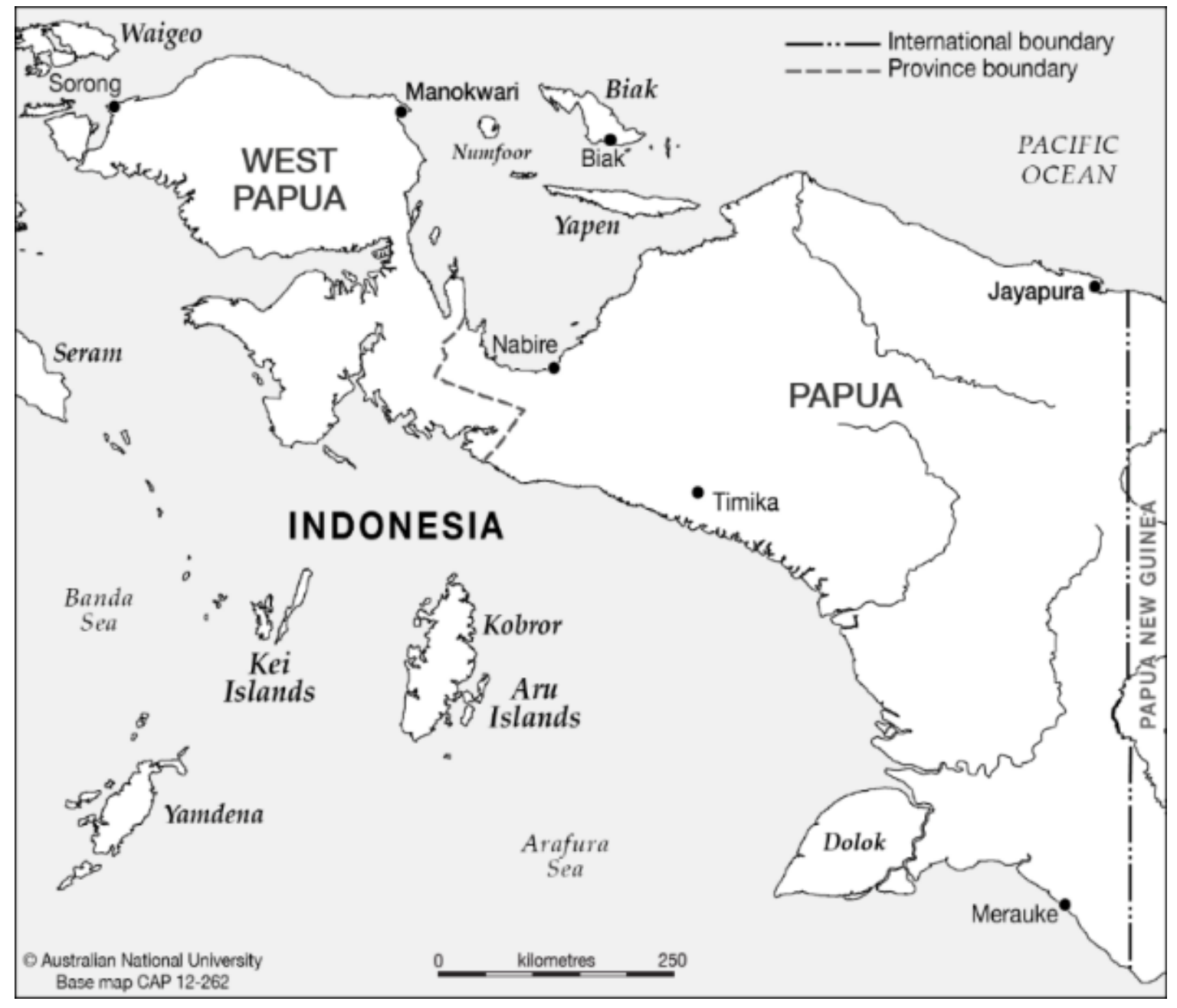

Figure 1: Map of West Papua, Indonesia. Source: CartoGIS Services, College of Asia and the Pacific, The Australian National University (2019).

West Papua's economic structure in 2013, as reflected in its 2013 Gross Regional Domestic Product at Current Price, mainly comprised manufacture (30\%); mining and quarrying (23\%); and construction (12\%); which altogether accounted for almost two-thirds of the regional economy (BPS-Statistics of Papua Barat Province, 2020). However, relying merely on these industries could be less sustainable as it may lead to non-renewable resources' depletion, 
environmental degradation, and regional disparity. Thus, diversifying regional economic structure and strengthening other renewable resource sectors could be strategic in the long run.

Tourism can be a key to accelerating the economic growth of Indonesia's second poorest province to achieve sustainable development. In recent decades, tourism has been growing rapidly in this region. This is evident from the variable but increasing number of visitors' overnight stays, which have quadrupled within the 2006-2018 period, and the large volume of disembarkations through regional ports and airports which increased twenty-fold over the same period (see Figure 2).

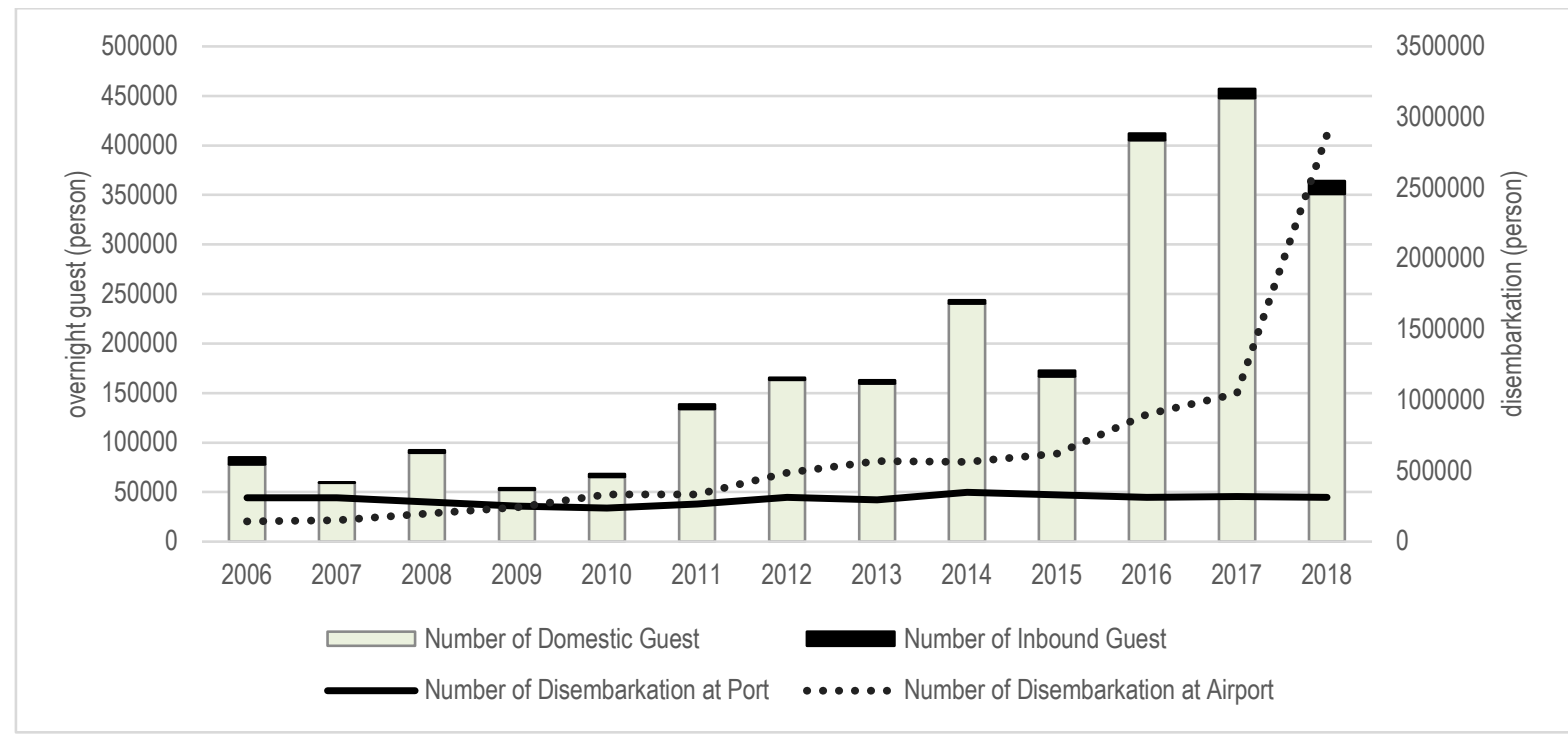

Figure 2: Number of overnight guests and disembarkation at regional ports and airports in West Papua, Indonesia, 2006-2018. Sources: Compiled by the author (BPS-Statistics of Papua Barat Province, 2016a,b).

West Papua has several favorable spaces for tourism to grow including its prime destination: Raja Ampat (Lonely Planet, 2018), a part of Bird's Head Seascape along with Triton Bay and Cenderawasih Bay (Bird's Head Seascape - Conservation International, n.d.). Of the thirteen subregions of the province, tourism activities and accommodation establishments are mainly concentrated in three subregions, namely Manokwari Regency, Sorong City, and Raja Ampat Regency.

Despite its tourism potential and growth, Papua Barat still struggles with poverty and sluggish economic growth. Therefore, it is necessary to understand the importance of the economic contribution of tourism on the regional economy and to uncover any issues or challenges that may affect this contribution. On that account, there are three objectives of this study. First, this study aims to calculate the economic contribution of tourism to the regional economy of Papua Barat by examining both domestic and inbound tourist spending. Second, it estimates the economic contribution of tourist expenditure by accommodation classification (3-star, 2-star, 1-star, and non-star). Finally, it describes the use of local resources, including the supply chain and human resources.

Pioneering evaluations on the economic contribution of tourism in this region, this study provides an empirical input to regional stakeholders, including local government and tourism-related authorities, in formulating strategies and policies to accelerate regional 
tourism-led economic growth. To this end, the paper has been divided into several sections. The first section introduces the background, issue, motivation, and significance of the study. The second section provides an overview of regional tourism development in West Papua, followed by data and methods of the study. Next, the third section presents empirical results and discussions regarding the impact of domestic and inbound visitor expenditure on the regional economy, the economic contribution of the regional accommodation sector based on the class of accommodations, the use of local resources by the same sector, and the discussion in the nexus between tourism and indigenous people. Finally, the paper concludes with recommendations for future related studies.

\section{Tourism in West Papua}

Previous studies have been conducted on the economic impact of tourism in island state(s) by using input-output multiplier (Archer \& Fletcher, 1996; Fletcher, 1989; Khan et al., 1990; Khan et al., 1995; Milne, 1987; Pratt, 2015; Steenge \& van de Steeg, 2010) but only a few take the case of subnational island boundary included Hawaii (Pratt, 2015), Penghu Island (Chen \& Var, 2010), the Balearic Islands (Polo \& Valle, 2008), and Bermuda (Archer, 1995a). Concerning the tourism-related sectors, some studies examine the multiplier effect of tourist expenditure at the disaggregated regional hotel and/or other accommodation levels, such as in the United States (Kim \& Kim, 2015) and Canada (Liu \& Var, 1982). As for the case of West Papua in particular, while previous studies on the economic valuation (Anna \& Saputra, 2017) and financial management (Atmodjo et al., 2017) of certain marine-based tourist destinations in this region are found, no study to date can be found on the economic contribution of tourism.

There are about 152 tourist attractions in West Papua. More than half of them are natural attractions with various activities like snorkeling, diving, whale watching, birdwatching, and trekking. Aside from natural attractions, the province also offers cultural attractions with activities such as pilgrimage and archeological site visits, agritourist objects, and maritime tourist objects. Some outstanding attractions have even become very popular among tourists, such as Raja Ampat Islands, Cendrawasih Cape, Triton Cape, Arfak Mountains Nature Reserve, Mansinam Island, and Tapurarang Historical Site.

Based on 2013 Domestic Tourism Statistics (Ministry of Tourism and Creative Economy Republic of Indonesia, 2013b), in terms of the type of tourist destinations visited, only $25 \%$ of visitors recorded visits to nature-based sites and only $6.25 \%$ visited artificial sites. The rest of the visitors did not record visits to any tourist sites, suggesting these visitors were more likely business travelers. West Papua recorded the longest average stay of domestic visitors in the whole country (23.38 days), which is 5.5 times the national average length of stay. Regarding transportation, water transport is the most popular choice of domestic visitors to access the province (62.5\%), followed by air transport (25\%) and others (12.5\%) e.g. taxi, motorcycle, and pedicab. Meanwhile, in terms of accommodation, only a quarter of domestic visitors stayed at hotels, while three-quarters stayed at their friends/relatives.

On average, the total expenditure of domestic visitors in West Papua was 1.51 million Rps (equivalent to US\$157.20) per trip. This was the third-largest after DKI Jakarta and Papua, and the second-largest after Bali for leisure, with more than half of overall total expenditure being spent on transport services. While the distribution of domestic visitors to 
West Papua by the main purpose of visit was evenly-dispersed by a quarter each for leisure, business, pilgrimage, and visiting friends and/or relatives, in terms of expenditure, business travelers contributed most to the total average expenditure per trip to the province $(52.1 \%)$. This was followed by leisure tourists (25.5\%), pilgrimage (11.7\%), and visiting friends/relatives (10.7\%; Ministry of Tourism and Creative Economy Republic of Indonesia, 2013b).

According to the 2013 Indonesia Passenger Exit Survey (2013), the proportion of inbound visitors to West Papua compared to all other regions in the whole country was only $0.03 \%$, and was dominated by visitors from the Philippines, the United States, and the United Kingdom. The average stay in the province was surprisingly high, at 10.67 days, which is the fourth-longest among all the provinces. This long stay was most likely due to the region's remoteness and lack of access. The average expenditure of inbound visitors in Indonesia by purpose of visit was highest among the 'other' category, e.g., humanitarian mission (US\$1,709.21), education (US\$1,530.56), health (US\$1,327.89), and leisure (US\$1,277.09). The accommodation sector received the largest proportion of inbound visitor expenditure with an average amount of US $\$ 558.63$ per trip (see Table 2).

\section{An overview of accommodation sector in West Papua}

The overview of the regional accommodation sector in West Papua to be presented in this paper is based on the year 2013, the base year of the latest West Papua IO table, and is retrieved from various sources, mainly from Hotel and Other Accommodation Statistics in Indonesia. Regional accommodation is disaggregated into various classes, namely 3-star, 2star, 1-star, and non-star. A star hotel or classified accommodation fulfills different criteria to be a 1-star, 2-star, 3-star, 4-star, or 5-star hotel. A non-star hotel or non-classified accommodation, on the other hand, is the accommodation that has not fulfilled the classification assessment criteria as a 1-star hotel yet. It is also referred to as a 'jasmine hotel' in Indonesian. In 2013, there were 11 classified accommodations (seven 3-star, two 2-star, and two 1-star hotels), and 89 non-classified (non-star) accommodations spread out across eight subregions of West Papua. Overall, based on the latest regional accommodation directory (BPS-Statistics of Papua Barat Province, 2018a) the number of total accommodations in West Papua has doubled to a total of 215 establishments in 2017, concentrated in Sorong City, Manokwari Regency, and Raja Ampat Regency.

In 2013, the accommodation sector in West Papua provided 1,525 jobs, where 730 employees (47.9\%) worked at classified accommodations and 795 employees (52.1\%) at nonclassified accommodations. Almost all of these employees were Indonesian (99.9\%). Concerning employment status, $71.3 \%$ of workers were permanent, $26.2 \%$ were contracted/part-time, and $2.4 \%$ were unpaid. Male workers dominate the labor force in the accommodation sector, particularly in permanent and contract/part-time jobs. On the other hand, relatively more female workers are found in administration work or unpaid work. Only 12.3\% have a tourism vocational education (BPS-Statistics Indonesia, 2013).

\section{Data}

The two most essential datasets used for this study are West Papua Input-Output Table 2013 and Indonesia Labor Force Survey in the $1^{\text {st }}$ Quarter of 2013. The vector of change in tourism 
expenditure is estimated based on multiple sources, including Domestic Tourism Statistics 2013, Passenger Exit Survey 2013, West Papua in Figures 2013, Statistics of Hotel and Other Accommodation in Indonesia 2013, Statistics of Hotel and Other Accommodation in West Papua 2013 and 2017, Occupancy Rate of Hotel Room 2014, Occupancy Rate of Hotel Room in West Papua 2016/2016, and Statistics of Transportation in West Papua 2018.

Published in 2015, the West Papua Input-Output Table 2013 is the first regional inputoutput table ever constructed for West Papua province. The regional input-output table consists of initially forty sectors (BPS-Statistics of Papua Barat Province, 2015). As sector classification in the datasets varies from one to another, it is necessary to aggregate and standardize the sectors before analysis. Due to the limitation and gap in sectoral details of the subject of expenditure of both groups of tourists, the following treatments are conducted. First, road transport, seawater transport, inland water transport (for river, lake, and crossing), and air transport are grouped as 'transportation'. Second, education, health, and social services, and other services are grouped as 'other services'. Further, aggregation is also carried out to cross-match Indonesia Labor Force Survey (SAKERNAS) 2013 Q1 and regional inputoutput table using Indonesia Standard Industrial Classification 2005 (3-digits) and 2009 (2digits). At this stage, the agriculture and fisheries sector are also grouped. Therefore, there are 27 sector classifications in total. However, the number of workers from the manufacture of fishery products and the manufacture of paper and printing are not represented in this survey. Furthermore, the subjects of tourist expenditures are reclassified based on the Indonesia InputOutput Table 2010 (BPS-Statistics Indonesia, 2015a) and the Scope of Tourism Activities in Indonesia Standard Industrial Classification 2015 (Ministry of Tourism Republic of Indonesia \& BPS-Statistics Indonesia, 2018). This new classification consists of accommodation; food service; transportation; warehouse, services related to transport, post, and courier; grocery and retail (excluding car and motorbike); leasing and business-related services; and other services. In addition, expenditure for 'others' is defined differently between domestic and inbound tourists: the former refers to services related to transport, including vehicle repairing services during travel, and the latter is defined as 'other services'. The overall sector reallocation for domestic and inbound tourist expenditure is seen in Table 1 and Table 2, respectively.

Table 1: Average expenditure per trip of domestic (non-residence) tourist visiting West Papua, 2013. Source: Ministry of Tourism and Creative Economy Republic of Indonesia, 2013b.

\begin{tabular}{lll}
\hline Subject of Expenditure & Reallocation & $\begin{array}{l}\text { Value (in 1000 } \\
\text { Rp) }\end{array}$ \\
\hline Accommodation & Accommodation & 93.75 \\
Food, beverage, \& tobacco & Food services & 245.63 \\
Transportation & Transportation & 851.75 \\
Entertainment, recreation, \& & Other services & - \\
cultural services & Leasing and business-related services & - \\
Other tourism services & Grocery \& retail (excl. car \& motorbike) & 307.50 \\
Shopping \& souvenir & Warehouse, service related to transport, & 12.50 \\
Others & post, \& courier & $1,511.13$ \\
\hline Average & & \\
\hline
\end{tabular}


Average expenditure of domestic visitors is recorded regionally based on the origin and destination as presented in the Indonesian National Socioeconomic Survey or SUSENAS (Ministry of Tourism and Creative Economy Republic of Indonesia, 2013b), while the average expenditure of inbound (foreign) visitors are currently not available at the regional level, but at the national level based on a survey at ten major ports of exit in Indonesia. In the future, it is strongly advised to conduct passenger exit surveys or any similar tourist expenditure surveys at regional ports/airports for future studies.

Table 2: Average expenditure per trip of inbound tourist visiting Indonesia and West Papua, 2013. Source: Authors' adjustment, Ministry of Tourism and Creative Economy Republic of Indonesia, 2013a.

\begin{tabular}{llll}
\hline Subject of Expenditure & Reallocation & Value for national (US\$) & $\begin{array}{c}\text { Adjusted value for } \\
\text { regional (in 1000 Rp) }\end{array}$ \\
\hline Accommodation & Accommodation & 558.63 & $7,489.69$ \\
Food \& beverages & Food services & 201.81 & $2,705.71$ \\
Domestic air transport & Transportation & 22.51 & 301.80 \\
Local transport & Transportation & 77.38 & $1,037.45$ \\
Shopping & Grocery \& retail (excl. car \& m.bike) & 71.26 & 955.40 \\
Souvenir & Grocery \& retail (excl. car \& m.bike) & 89.85 & $1,204.64$ \\
Entertainment & Other services & 32.56 & 436.54 \\
Health \& wellness & Other services & 23.23 & 311.45 \\
Education & Other services & 1.91 & 25.61 \\
Local tour package & Leasing \& business-related services & 25.99 & 348.45 \\
Sightseeing (entrance fees & Leasing \& business-related services & 23.47 & 314.67 \\
commercial tourist object) & Leasing \& business-related services & 4.37 & 9.28 \\
Tour guide service & Other services & $1,142.25$ & 58.59 \\
Others & & & 124.42 \\
\hline Average & & & $15,314.42$ \\
\hline
\end{tabular}

Due to the region's remoteness and lack of access (fewer flights and voyages) both intraand inter-regionally, excursion (day trips) are unlikely to occur. Following this logic, it is a plausible assumption that the number of visitors in the region is represented by the number of guests at regional accommodations. The number of domestic (non-residents) and inbound (foreign) tourists in West Papua in 2013 were 159,775 and 3,095 persons, respectively (BPSStatistics Indonesia, 2018). Compared to inbound tourism, domestic tourism dominates the regional tourism market in terms of the number of visitors (98\%) and average length of stay, except for average expenditure per trip.

The vector of change in tourism demand $\left(Y_{\text {tour }}\right)$ for both domestic and inbound tourists are calculated similarly. The only difference is that inbound tourist expenditure is regionalized before computation because it originates from national data. Therefore, inbound tourist expenditure is calibrated first by multiplying the national inbound tourist average expenditure by the ratio of regional to national average length of stay. Details of adjusted value for regional can be seen in Table 2. Afterward, the number of domestic and inbound visitors (num tour $_{\text {) }}$ is multiplied by its average expenditure per trip ( $\left.a v g \_\exp _{\text {tour }}\right)$, respectively, as shown below. The average length of stay in the region is not involved in the calculation, because the average expenditure is already calculated per trip.

$$
Y_{\text {tour }}=\text { num }_{\text {tour }} \text { avg_exp } \operatorname{exur}_{\text {tour }}
$$


The second aim of the study evaluates the impact of tourist spending on accommodations on the regional economy by classifying the accommodations into 3-star, 2star, 1-star, and non-star classes. The vector of change in demand at each class of accommodation sector $\left(Y_{\text {lodge }}\right)$ is obtained by multiplying the number of room nights $\left(n h t_{\text {lodge }}\right)$ by the average room rate per night $\left(\right.$ avg_rte $\left._{\text {lodge }}\right)$ for each class.

$$
Y_{\text {lodge }}=n h t_{\text {lodge }} \text { avg_rte } \text { lodge }_{2}
$$

Table 3: Number of guest, average length of stay, occupancy rate, room night, guest night, and average room rate by accommodation type and class, West Papua, 2013. Source: BPSStatistics Indonesia (2015b).

\begin{tabular}{|c|c|c|c|c|c|c|c|c|c|}
\hline \multirow{2}{*}{$\begin{array}{l}\text { Accomm. } \\
\text { Type/Class }\end{array}$} & \multirow{2}{*}{$\begin{array}{l}\text { Room } \\
\text { Occup. } \\
\text { Rate }\end{array}$} & \multirow{2}{*}{$\begin{array}{l}\text { Bed } \\
\text { Occup. } \\
\text { Rate }\end{array}$} & \multirow{2}{*}{$\begin{array}{l}\text { No. of } \\
\text { Room } \\
\text { Night } \\
\text { (Rn) }\end{array}$} & \multirow{2}{*}{$\begin{array}{l}\text { No. of } \\
\text { Guest } \\
\text { Night } \\
\text { (Gn) }\end{array}$} & \multicolumn{2}{|c|}{$\begin{array}{l}\text { No. of Guest } \\
\text { (1000s of person) }\end{array}$} & \multicolumn{2}{|c|}{$\begin{array}{l}\text { Avg. length of stay } \\
\text { (nights) at } \\
\text { accomm. }\end{array}$} & \multirow{2}{*}{$\begin{array}{l}\star \text { Avg. } \\
\text { Room } \\
\text { Rate (in } \\
\text { Rp) }\end{array}$} \\
\hline & & & & & $\begin{array}{l}\text { Inbou } \\
\text { nd }\end{array}$ & $\begin{array}{l}\text { Domest } \\
\text { ic }\end{array}$ & $\begin{array}{l}\text { Inboun } \\
\text { d }\end{array}$ & $\begin{array}{l}\text { Domest } \\
\text { ic }\end{array}$ & \\
\hline Classified & 51.78 & 48.94 & 149062 & 204962 & 1.9 & 86.5 & 2.64 & 2.31 & 573000 \\
\hline 3-Star & 50.77 & 48.85 & 89911 & 125715 & 0.8 & 60.9 & 2.23 & 2.03 & 675357 \\
\hline 2-Star & 42.57 & 36.37 & 23656 & 28052 & 0.1 & 5.2 & 1.00 & 5.40 & 422750 \\
\hline 1-Star & 64.24 & 60.70 & 35495 & 51195 & 1.0 & 20.4 & 3.07 & 2.35 & 365000 \\
\hline $\begin{array}{l}\text { Non-Classified } \\
\text { (Non-Star) }\end{array}$ & 29.54 & 26.91 & 131335 & 178534 & 1.2 & 73.3 & 3.51 & 2.38 & 251028 \\
\hline
\end{tabular}

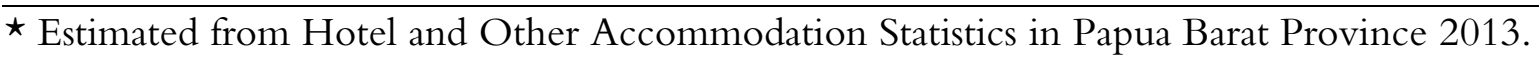

Aside from the quantitative analysis, a qualitative approach (through interviews) was conducted to investigate the use of local resources by regional accommodation establishments in terms of commodities and employment. Initially, these interviews were to be carried out with about one-third (35/100) of total accommodations, as listed in the Statistics of Hotel and Other Accommodation in West Papua 2013 (BPS-Statistics of Papua Barat Province, 2013) between March 22-April 4, 2019. However, several establishments that began to operate after 2013 were also included in the study, while some previously operational establishments went out of business and were unavailable for interviews.

\section{Method}

An input-output multiplier analysis was conducted to measure the contribution of tourism, as represented by domestic and inbound visitor expenditure, on the regional economy, with a special focus on the impact of tourist expenditure at various classes of regional accommodations. Tourism and accommodation sector impact on output, income, valueadded, and employment is calculated according to Klijs \& Marts (2012). Consequently, total output needed to deliver final demand of visitor $(X)$ is mathematically expressed as a multiplication of the Leontief inverse matrix $\left\{[I-A]^{-1}\right\}$ by visitor expenditure $(Y)$, as seen in the following equation.

$$
X=[I-A]^{-1} Y
$$


A Leontief inverse matrix refers to an inversed reduction of the identity matrix $(I)$ by technical coefficient matrix $(A)$, with $Y$ being substituted by the domestic and inbound visitors expenditure $\left(Y_{\text {tour }}\right)$ and tourist expenditure at the regional accommodation sector

per accommodation class $\left(Y_{\text {lodge }}\right)$. Furthermore, the impact on income, value-added, and employment is calculated by multiplying the simple output multiplier $(X)$ by the ratio of income, value-added, and number of employments as derived from the regional input-output table and the national labor survey to the total output by sector, respectively.

\section{Results and discussion: impact of tourism on West Papua's economy}

In 2013, the domestic visitor expenditure in West Papua was 410.05 billion Rps ( \pm US $\$$ $42.66 \mathrm{M})$ as additional output, predominantly generated from transportation, grocery and retail (minus car and motorbike), food services, and accommodation, respectively. On the other hand, the inbound visitor expenditure was 87.55 billion Rps ( \pm US\$ 9.11M) as additional output, mainly from accommodation, fisheries, and grocery and retail (minus car and motorbike). The strong contribution of domestic visitors in the transportation sector was most likely due to the higher interregional transport cost, especially to Indonesia's easternmost regions. Inbound visitors, on the other hand, tended to stay longer at their destination and their expenditure was relatively higher for accommodation.

Some sectoral outputs are above average even though those sectors are not directly affected by visitor expenditure, such as agriculture; fisheries; manufacture of oil, petroleum, and gas; mining and quarrying; manufacture of food, beverage, and tobacco; furniture and forestry products; other manufactures; and finance. These are indirect impacts. In addition, visitor expenditure amplifies the demand for fisheries and agriculture, which are most likely associated with lower-income households. Hence, tourism may be viewed as a good stimulus to boost regional economic growth.

Furthermore, 241.44 billion Rps of value-added, 76.36 billion Rps of income, and 3,847 jobs were generated by domestic visitors (see Table 4). On the other hand, inbound visitors bring forth 47.41 billion Rps of value-added, 14.19 billion Rps of income, and 969 jobs. The contribution of tourist expenditure to West Papua economy was minor, however, compared to Indonesia's most visited province, Jakarta, whose contribution in 2013 was about 64.02 trillion Rps in value-added, 17.97 trillion Rps in income, 1.94 trillion Rps in indirect tax, and 665,615 employment opportunities (Remi et al., 2017).

Overall, the impact of expenditure of inbound tourists on the regional economy, both in monetary and jobs, is smaller than that of domestic tourists. However, the output multiplier is larger: 1.847 compared to 1.698 for inbound and domestic tourists, respectively. Attracting more inbound tourist expenditure can be a good strategy to maximize the tourism-led economic benefit for West Papua. Further, the multiplier of overall output from both types of tourists is larger than the regional overall output multiplier (1.603), highlighting the importance of tourism to the regional economy. This is similar to the case of Singapore (Khan et al., 1995). 
Table 4: Contribution of the domestic and inbound visitor spending on output, value-added, income, and employment in West Papua, Indonesia. Source: Authors' calculation.

\begin{tabular}{|c|c|c|c|c|c|c|c|c|}
\hline \multirow[t]{2}{*}{ Sectors } & \multicolumn{2}{|c|}{$\begin{array}{l}\text { Output (in mill. } \\
\text { Rp) }\end{array}$} & \multicolumn{2}{|c|}{$\begin{array}{l}\text { Value Added (in } \\
\text { mill. Rp) }\end{array}$} & \multicolumn{2}{|c|}{$\begin{array}{l}\text { Income (in mill. } \\
\mathrm{Rp} \text { ) }\end{array}$} & \multicolumn{2}{|c|}{$\begin{array}{l}\text { Employment (in } \\
\text { jobs) }\end{array}$} \\
\hline & Domestic & Inbnd. & Domestic & Inbnd. & Domestic & Inbnd. & Domestic & Inbnd. \\
\hline Agriculture & 7389 & 3674 & 6404 & 3184 & 1575 & 783 & 756 & 376 \\
\hline Livestock & 829 & 372 & 684 & 307 & 250 & 112 & 3 & 1 \\
\hline $\begin{array}{l}\text { Agriculture service \& } \\
\text { hunting }\end{array}$ & 251 & 120 & 201 & 96 & 53 & 25 & 26 & 12 \\
\hline Forestry & 1737 & 362 & 1480 & 309 & 339 & 71 & 26 & 5 \\
\hline Fisheries & 16595 & 9965 & 10856 & 6519 & 2137 & 1283 & 82 & 49 \\
\hline $\begin{array}{l}\text { Manufacture of oil, } \\
\text { petroleum, \& gas }\end{array}$ & 31663 & 2807 & 13577 & 1204 & 3557 & 315 & 6 & 1 \\
\hline Mining \& quarrying & 9874 & 879 & 8435 & 751 & 1390 & 124 & 0 & 0 \\
\hline $\begin{array}{l}\text { Manufacture of fishery } \\
\text { products }\end{array}$ & 3225 & 1626 & 1732 & 873 & 334 & 169 & 0 & 0 \\
\hline $\begin{array}{l}\text { Manufacture of food, } \\
\text { Beverage, \& tobacco }\end{array}$ & 14534 & 5519 & 9660 & 3668 & 2828 & 1074 & 299 & 113 \\
\hline $\begin{array}{l}\text { Furniture \& forestry } \\
\text { products }\end{array}$ & 7648 & 1027 & 3328 & 447 & 874 & 117 & 18 & 2 \\
\hline $\begin{array}{l}\text { Manufacture of paper \& } \\
\text { printing }\end{array}$ & 3793 & 932 & 2790 & 686 & 876 & 215 & 0 & 0 \\
\hline $\begin{array}{l}\text { Manufacture of cement \& } \\
\text { non-metal quarrying }\end{array}$ & 186 & 23 & 93 & 11 & 34 & 4 & 2 & 0 \\
\hline Other manufactures & 17371 & 2051 & 10876 & 1284 & 3514 & 415 & 88 & 10 \\
\hline Electricity, gas, \& water & 5672 & 1570 & 741 & 205 & 167 & 46 & 42 & 12 \\
\hline Construction & 1866 & 198 & 1405 & 149 & 561 & 60 & 4 & 0 \\
\hline $\begin{array}{l}\text { Trade of cars, motorbikes, } \\
\& \text { its reparation service }\end{array}$ & 695 & 185 & 572 & 153 & 188 & 50 & 2 & 1 \\
\hline $\begin{array}{l}\text { Grocery \& retail (excl. car } \\
\& \text { motorbike) }\end{array}$ & 56688 & 8852 & 31639 & 4940 & 8981 & 1402 & 644 & 100 \\
\hline Transportation & 142383 & 5100 & 94916 & 3400 & 33740 & 1208 & 1205 & 43 \\
\hline $\begin{array}{l}\text { Warehouse, service related } \\
\text { to transport, post, \& courier }\end{array}$ & 7039 & 322 & 1562 & 71 & 565 & 26 & 24 & 1 \\
\hline Accommodation & 16083 & 23296 & 6323 & 9158 & 1656 & 2399 & 20 & 29 \\
\hline Food service & 40505 & 8794 & 16282 & 3535 & 6017 & 1306 & 390 & 85 \\
\hline Information \& technology & 4791 & 735 & 2910 & 446 & 803 & 123 & 6 & 1 \\
\hline Finance & 7855 & 1753 & 6996 & 1561 & 2139 & 477 & 43 & 9 \\
\hline Real estate & 1656 & 291 & 1367 & 240 & 74 & 13 & 2 & 0 \\
\hline $\begin{array}{l}\text { Leasing \& business-related } \\
\text { services }\end{array}$ & 4730 & 3019 & 2534 & 1617 & 780 & 498 & 115 & 73 \\
\hline $\begin{array}{l}\text { Government } \\
\text { administration, defense, \& } \\
\text { Social insurance }\end{array}$ & 2874 & 634 & 2874 & 634 & 2058 & 454 & 21 & 5 \\
\hline Other services & 2117 & 3444 & 1203 & 1958 & 873 & 1420 & 24 & 39 \\
\hline Total & 410051 & 87548 & 241440 & 47405 & 76364 & 14190 & 3847 & 969 \\
\hline
\end{tabular}

The overall income multiplier for domestic and inbound tourists is 0.316 and 0.299 , respectively; and in terms of employment, the overall employment multiplier is 0.016 and 0.020 , respectively. This suggests that domestic tourists contributed more to the regional labor's income, while inbound tourists generate more employment. However, the difference between the two in both terms is not large. 


\section{Analysis of regional accommodation sector by classes}

Based on the accommodation class, tourist expenditure at 3-star hotels was the biggest contributor to West Papua's economy. In total, tourist expenditure at 3-star accommodations contributed 118.15 billion Rps ( \pm US $\$ 12.29 \mathrm{M}$ ) of output, 60.72 billion Rps ( \pm US $\$ 6.32 \mathrm{M}$ ) of value-added, 15.53 billion Rps ( \pm US $\$ 1.62 \mathrm{M}$ ) of income, and 1,151 jobs. Despite its higher room rate per night, 3-star accommodation had a high volume of overnight stay, which might indicate guests' preference for standardized full-service accommodations.

As for non-star accommodations, they generated 64.15 billion Rps ( \pm US $\$ 6.67 \mathrm{M}$ ) of output, 32.97 billion Rps ( \pm US $\$ 3.43 \mathrm{M}$ ) of value-added, 8.43 billion Rps ( \pm US\$ $0.88 \mathrm{M}$ ) of income, and 625 jobs. These figures are most likely driven by a large number of room nights (number of guests $x$ length of stay), as the result of the greater number of establishments compared to classified or starred accommodations. Their room occupancy rates, however, were the lowest among the four classes. Therefore, increasing the occupancy rate of non-star accommodations may lead to a greater economic impact on the regional economy, and may provide wider benefits to the community, as they were primarily owned and managed by lower-middle-class households. See Table 5 for details including the contribution for 1-star and 2-star accommodation.

Although the aggregated classified hotel outnumbered the non-classified accommodation (11:89), the classified hotels capture about $72 \%$ of total receipts for the regional accommodation sector including seven non-indigenously owned three-star establishments that capture $52 \%$ alone. Similar results were found in Bermuda were large hotels captured 54\% of total tourist expenditure (Archer, 1995b), and in Victoria, BC, Canada, where seven externally-owned establishments representing $16 \%$ of the sample comprise more than three-quarter of tourist receipts (Liu \& Var, 1982). On the other hand, Polo et al. (2008) found that one-, two-, and three-star hotels contributed more than double to the Balearic Islands' economy compared to four and five-star hotels. Furthermore, while accommodation's strongest linkage to fisheries is an advantage, manufacture of food, beverage, and tobacco sector, on the other hand, should be observed carefully due to its heavy dependence on import, which might lead to larger leakage, especially in the exploratory and development stage of tourism development (Pratt, 2011).

Table 5: Above-average sectoral contribution induced by visitor expenditure at regional accommodation by class, West Papua. Source: Authors' calculation.

\begin{tabular}{|c|c|c|c|c|c|}
\hline Sectors & Contributions & 3-star & 2-star & 1-star & Non-star \\
\hline \multirow{4}{*}{ All sectors } & Output (in mill. Rps) & 118150 & 19459 & 25208 & 64149 \\
\hline & Value-Added (in mill. Rps) & 60722 & 10001 & 12956 & 32969 \\
\hline & Income (in mill. Rps) & 15529 & 2558 & 3313 & 8432 \\
\hline & Employment (in jobs) & 1151 & 190 & 246 & 625 \\
\hline \multirow{4}{*}{ Fisheries } & Output (in mill. Rps) & 19787 & 3259 & 4222 & 10743 \\
\hline & Value-Added (in mill. Rps) & 12945 & 2132 & 2762 & 7028 \\
\hline & Income (in mill. Rps) & 2549 & 420 & 544 & 1384 \\
\hline & Employment (in jobs) & 97 & 16.04 & 21 & 53 \\
\hline \multirow{4}{*}{$\begin{array}{l}\text { Manufacture of food, } \\
\text { beverage, \& tobacco }\end{array}$} & Output (in mill. Rps) & 8336 & 1373 & 1779 & 4526 \\
\hline & Value-Added (in mill. Rps) & 5540 & 912 & 1182 & 3008 \\
\hline & Income (in mill. Rps) & 1622 & 267 & 346 & 881 \\
\hline & Employment (in jobs) & 171 & 28 & 37 & 93 \\
\hline \multirow{4}{*}{ Agriculture } & Output (in mill. Rps) & 6459 & 1064 & 1378 & 3507 \\
\hline & Value-Added (in mill. Rps) & 5597 & 922 & 1194 & 3039 \\
\hline & Income (in mill. Rps) & 1377 & 227 & 294 & 748 \\
\hline & Employment (in jobs) & 661 & 109 & 141 & 359 \\
\hline
\end{tabular}




\section{Local resources use in the regional accommodation sector}

While a quantitative approach can depict the impact of tourism on the regional economy in general and the contribution of the accommodation sector to the economy in terms of output, value-added, income, and employment in particular, it is unable to explain how these benefits are distributed. Remote islands are usually vulnerable in terms of resources availability (Kakazu, 2011) and variety (Leunufna \& Evans, 2014; Mollet, 2011). Therefore, they usually rely on resources from the main island and other neighboring regions. This section aims to discuss the use of local resources; commodities and human resources; by the regional accommodation sector to meet the tourism demand.

Leakage refers to an economic loss that arises due to a lack of self-sufficiency of a hosting state/region to meet its market demand (Wiranatha et al., 2017). In this study, two kinds of leakages will be discussed, namely commodity import and employment of foreigners and non-residents. The phenomenon of leakage from commodity import can be easily understood in the following scenario. The increasing number of visitors in West Papua stimulates demand for accommodation including food and beverages, which consequently elevates the demand for agriculture produce (e.g., rice). This can only be supplied in limited capacity domestically, most likely due to the lack of agricultural land and technology. In addition, West Papua relies on fish, animals, and sago as native staple food instead (Mollet, 2011). Consequently, the incapacity of the local market to satisfy the new demand for rice drives the supply of rice from other areas, either the rest of the country (ROC) and/or the rest of the world (ROW). Therefore, no matter how much revenue could be made within the destination, as long as leakage to the outside region remains high, tourism contribution to regional economic growth is subdued (Suryawardani et al., 2016).

Leakages in remote archipelagic regions in developing countries, like West Papua in Indonesia, are most likely large (Boz, 2011; Hampton et al., 2018; Kakazu, 2008; Pratt et al., 2018). To gain insight into this, in-depth qualitative interviews were conducted with 35 representatives from various accommodation establishments. These establishments comprised twenty-nine domestic-owned establishments, four private-government-owned establishments, and two foreign-owned hotels. Only three out of the thirty-five establishments were operated under international hotel chain management contracts.

The interviews show that, except for fish and wood furniture, about $90 \%$ of commodities input to regional accommodations were supplied from other regions of Indonesia. While no direct import from overseas was detected, some imported products such as liquor and diving instruments were identified during observation, which may imply a minor, indirect leakage to overseas arising from retail and entertainment/recreation activities. Expenditures made by lodgings in the three subregions varied, but there was a major similarity, namely wood products, and furniture, which were supplied intra-regionally, especially as timber from this province is popular and remarkably affordable thanks to lower transport costs.

The variable costs of full-service lodgings other than utilities, such as food and beverages, were acquired from local traditional markets that offered agricultural products of various qualities, quantities, and values but mostly supplied from other regions. Moreover, tourist demand for food and beverages during their stay has increased the demand for produce, which were not produced locally in the first place and further enlarged the leakage. This lack of local supply to meet the excess demand driven by tourism is suspected as the major cause of sluggish economic growth in the destination. 
The interviews also show that classified (starred) accommodations mostly obtained their daily produce from third parties or outsourcing agents and individuals; very few obtained it independently through their chefs. While price, quality, and availability were the main factors when choosing the produce, there was no special preference in terms of origin of the produce. Therefore, even though the produce were obtained from regional traditional markets and stores intra-regionally, a significant proportion of produce such as vegetables and fruits are suspected to be brought in from other regions. On this note, future studies that deal with the extent of commodity leakage through regional retail and grocery sectors are urgently necessary.

Furthermore, chemical supplies and room amenities for all classified and non-classified accommodations were obtained from sources outside the region, such as in Jakarta and Surabaya, because, unlike produce, room amenities such as soap, shampoo, toothbrush, and paste have a longer shelf life and are cheaper if purchased at wholesale. This dependency of regional accommodation on interregional imported chemical supplies and room amenities does not only lead to an economic loss but also has environmental risks. On this note, imposing regional regulations to limit the use of imported chemical supplies and room amenities and promote the use of locally produced environmentally-friendly, organic room amenities could be a good strategy to achieve multiple objectives.

In West Papua, however, labor is distinguished into four categories, namely foreign labor, national residents, regional residents, and Indigenous Papuans (OAP [orang asli papua]). National residents, regional residents, and OAPs are all Indonesian nationals. Regional residents hold national identification cards that acknowledge them as citizens of West Papua. Most regional residents were transmigrated from other islands, i.e., Java and Sulawesi, in the 1960s. OAP, on the other hand, is a special racial identity belonging to native Papuan islanders (Melanesian ethnic group; Gietzelt, 1989).

From the qualitative interviews, it is found that the current engagement of Indigenous Papuan in the regional accommodation sector is still underrepresented, mainly due to the lack of basic tourism and hospitality knowledge and skills and the existence of some habitual issues. Of the 1,073 individuals working in the 35 accommodation establishments, in particular, $50.09 \%$ are identified as regional residents, $25.37 \%$ as national residents, $23.07 \%$ as OAPs, and $1.47 \%$ as foreigners. This finding suggests the major proportion of national labor $(98.5 \%)$ compared to foreign labor, which mostly comes from South Africa and China. The labor force is dominated by full-time (permanent) workers (67\%), followed by annual contract workers (24.91\%) and part-time/daily workers (8.09\%).

The proportion of Indigenous Papuans in the overall workforce was smaller than that of non-Papuan labor, especially in the accommodation sector. Further qualitative investigation reveals two major factors why employers recruit OAPs: (1) commitment to developing the Papuan community through employment; and (2) regulation from the Ministry of Manpower that requires the employment of local workers. On the other hand, four factors discourage employers from engaging OAPs in the workforce: (1) OAPs' attitude and behavior that fail to comply with the industry's standard, e.g., sudden resignation and alcohol abuse before and while on duty; (2) limited knowledge and skill about the hospitality industry; (3) limited number of applicants, as OAPs tended to be interested in working unskilled jobs at ports, in coffee and canning factories, or as security personnel or civil servants; and (4) different culture or way of life (i.e., aboriginal hunting) and communication (language) barrier. 
Regarding regional workers, two factors are driving their employment: (1) transfer of knowledge and experience to local employees; and (2) their good attitude and behavior. On the other hand, several factors inhibit employers from hiring them: (1) demand for high salaries; (2) high turnover due to offers from new hotels; and (3) lack of formal education in the tourism and hospitality area within the region.

Workers from other regions and overseas were hired mainly due to two factors, namely: (1) the possession of the necessary qualification and working experience; and (2) the employers' preference to hire candidates from their hotel chain network and/or relatives. But the extra cost for inbound mobilizing and housing became the main consideration not to recruit manpower from other regions.

The analysis in this subsection is based on the recent data from 2019. Therefore, the findings in this subsection cannot be incorporated into those in the two previous subsections whose results are derived from the 2013 year-based datasets.

\section{Challenges and opportunities in the nexus between tourism and Indigenous Papuans}

The socioeconomic gap between Indigenous Papuans and "settlers" from the rest of Indonesia has triggered several major interracial clashes and riots that have been taking place since West Papua was incorporated onto the Republic of Indonesia in the early 1960s, the most recent of which occurred in 2019 at the same year when this research was documented. Based on our interview with a tribal leader representative from Indigenous Papuan community, the economic development from tourism in West Papua Province was not the priority; preserving environment (Camara-Leret et al., 2019) and rights of Indigenous Papuans on ancestral land are the two most crucial agendas (Mollet, 2011). Foreign investment in tourism through the development of (multi)national chain hotels and resorts, for example, was not a priority, especially in the rural and remote islets where poverty has been most severe.

Investment in tourism by foreigners and those from outside the province were perceived as "invasive". The tourism sector, as a labor-intensive sector, has employed Indigenous people less than its expected standard of $30 \%$. This situation might discourage Indigenous people to trust in regional development through tourism. Therefore, tourism development in this region, especially in the rural area and remote islets, is suspected as a form of soft colonialization.

Despite leakages, unfair development, and confrontation between Indigenous people and the Indonesian government over rights on ancestral land and its use, tourism is seen as a passport for peace and prosperity. Whilst there was a slowdown in big chain hotels and resorts development (mentioned above), local homestays run by Indigenous people have emerged recently. Particularly in Raja Ampat Islands, these family-run businesses were owned and managed by the Indigenous Papuan islanders and were established mainly around the seashore throughout inhabited islets. These local homestays have been associated with Raja Ampat Homestay Association since 2013 (Raja Ampat Homestay Association, n.d.). Additionally, homestays were supported by regional government at its initial phase included procurement assistance of standard guest bedroom goods and were tax exempt.

Furthermore, this homestay association produces US $\$ 1.5 \mathrm{M}$ gross revenue annually and provides 600 local jobs in homestay, fishing, and agriculture (Elson et al., 2016). In addition, unlike the formal accommodation sector, the homestay association promotes $100 \%$ employment for Indigenous Papuan (Seventythree Pte Ltd., 2019). 


\section{Conclusions}

This study discusses the contribution of the tourism and accommodation sector on the regional economy of West Papua, Indonesia, while describing the engagement of local commodities and human resources by the regional accommodation sector, as well as the role of Indigenous Papuan in tourism. The economic contribution of tourism is significant, as shown from the higher overall output multiplier compared to the regional output multiplier (1.603). As found in Singapore (Khan et al., 1995), the Balearic Islands' economy (Polo \& Valle, 2008), and Bermuda (Archer, 1995a), tourism is important to subnational remote island economies.

Furthermore, domestic visitor expenditure generated 241.44 billion Rps of valueadded, 76.36 billion Rps of income (equivalent to US\$25.12 million and US\$7.94 million, respectively) and 3,847 jobs, with the strongest linkage to transportation, grocery and retail (minus car and motorbike), food services, and accommodation, while inbound visitors spending brought forth 47.41 billion Rps of value-added, 14.19 billion Rps of income (equivalent to US $\$ 4.93$ million and US\$ 1.48 million, respectively), and 969 jobs, with robust linkages to accommodation, fisheries, and grocery and retail (minus car and motorbike). Expenditure of domestic tourists in the region is found to be larger than that of inbound tourists. However, the overall output multiplier led by inbound tourist expenditure (1.847) is found to be larger than domestic tourists (1.698), which suggests the importance of encouraging inbound tourist spending in the region in boosting West Papua's economy.

Based on accommodation class, 3-star accommodations are found to give the highest contribution to the regional economy, amounting to 118.15 billion Rps ( \pm US\$ $12.29 \mathrm{M}$ ) of output, 60.72 billion Rps ( \pm US $\$ 6.32 \mathrm{M}$ ) of value-added, 15.53 billion Rps ( \pm US $\$ 1.62 \mathrm{M}$ ) of income, and 1,151 jobs, followed by non-star, 1-star, and 2-star accommodations, respectively. The indirect impact of the accommodation sector was particularly strong with food-related primary sectors, which differ from the experience of more advanced economies with developed services-related sectors (Kim \& Kim, 2015). However, this strong intersectoral linkage between accommodation and fisheries and agriculture provides a good example of tourism's role in alleviating poverty (Croes \& Rivera, 2017).

Based on qualitative interviews with representatives from regional accommodation enterprises, it is found that a considerable proportion of tourist expenditures leak out to other regions due to high imports of commodities such as agricultural produce and manufactured food, beverage, and tobacco. Furthermore, the proportion of Indigenous Papuans (OAP) working in regional accommodation enterprises is higher than that of foreigners but lower than that of regional residents and national non-residents. This can be attributed to their lack of basic knowledge and skill about the hospitality industry and the existence of some "habitual issues". If this situation remains, tourism development in West Papua may only satisfy nonIndigenous stakeholders and has less effect to repair relationships between West Papua and Indonesia.

On the other hand, local homestays and small-medium businesses run by Indigenous Papuan families were effective to improve the Indigenous household economy (through income and employment). This should be promoted further. The accommodation sector managed to provide jobs to local youth labor, who have limited access to higher education in the region, especially in the field of tourism and hospitality. This condition can be improved further by 
providing affordable education to reach the whole area, especially the outer islets, e.g., through online courses, to prepare local youth for the upcoming tourism development.

This study is still at a preliminary stage, and follow-up research needs to be pursued with more comprehensive analyses of interregional and interisland (intra-region) supply chains, focusing on the expenditure patterns of accommodation establishments and their purchasing behavior. In addition, future research could address other types of accommodations that are not discussed in this study, such as liveaboards and ecolodges in small outer islets. Finally, to improve the depth and quality of analysis on the economic impacts of tourism in micro levels, such as at Indigenous and in-migrants labor (Batey et al., 1987; Miller \& Blair, 2009), it is also suggested to employ the income multiplier type III in future.

\section{Acknowledgments}

We are grateful and thank the Island Studies Journal editors and anonymous reviewers for their constructive criticisms, which have assisted us improve this manuscript. This work is supported by the Tokyo Human Resources Fund for City Diplomacy.

\section{References}

Anna, Z., \& Saputra, D.S. (2017). Economic valuation of whale shark tourism in Cenderawasih Bay National Park, Papua, Indonesia. Biodiversitas, 18, 1026-1034. https://doi.org/10.13057/biodiv/d180321

Archer, B. (1995a). Importance of tourism for the economy of Bermuda. Annals of Tourism Research, 22(4), 918-930. https://doi.org/10.1016/0160-7383(95)00018-1

Archer, B. (1995b). The impact of international tourism on the economy of Bermuda, 1994. Journal of Travel Research, 34(2), 27-30.

Archer, B., \& Fletcher, J. (1996). The economic impact of tourism in the Seychelles. Annals of Tourism Research, 23(1), 32-47. https://doi.org/10.1016/0160-7383(95)00041-0

Atmodjo, E., Lamers, M., \& Mol, A. (2017). Financing marine conservation tourism: Governing entrance fees in Raja Ampat, Indonesia. Marine Policy, 78, 181-188. https://doi.org/10.1016/j.marpol.2017.01.023

Batey, P.W.J., Madden, M., \& Weeks, M.J. (1987). Household income and expenditure in extended input-output models: A comparative theoretical and empirical analysis. Journal of Regional Science, 27(3), 341-356. https://doi.org/10.1111/j.14679787.1987.tb01166.x

Bird's Head Seascape - Conservation International. (n.d.). About the Bird's Head Seascape. https://birdsheadseascape.com/about-the-birds-head-seascape

Boz, M. (2011). Leakages and value added in international tourism revenues: Tourism satellite account as a measurement method. International Journal of Business and Social Science, 2(24), 198-206.

BPS-Statistics Indonesia. (2018). Home: Tourism. https://www.bps.go.id/subject/16/Pariwisata.html\#subjekViewTab3 |accordiondaftar-subjek2 
BPS-Statistics Indonesia. (2017). Total area and number of islands by province, 2002-2016. https://www.bps.go.id/statictable/2014/09/05/1366/luas-daerah-dan-jumlahpulau-menurut-provinsi-2002-2016.html

BPS-Statistics Indonesia. (2015a). Tabel input output Indonesia 2010. Jakarta: BPS-Statistics Indonesia.

BPS-Statistics Indonesia. (2015b). Tingkat penghunian kamar hotel 2014. Jakarta: BPS-Statistics Indonesia.

BPS-Statistics Indonesia. (2013). Statistik hotel dan akomodasi lainnya di Indonesia 2013. Jakarta: BPS-Statistics Indonesia.

BPS-Statistics of Papua Barat Province. (2020). [2010 Version] Gross Domestic Regional Bruto At Current Prices, 2008-2019.

https://papuabarat.bps.go.id/dynamictable/2019/04/30/105/-seri-2010-produkdomestik-regional-bruto-atas-dasar-harga-berlaku-2008-2019.html

BPS-Statistics of Papua Barat Province. (2018a). Direktori Hotel dan Akomodasi Lainnya Provinsi Papua Barat 2017. Manokwari: BPS-Statistics of Papua Barat Province.

BPS-Statistics of Papua Barat Province. (2018b). Provinsi Papua Barat Dalam Angka 2018. Manokwari: BPS-Statistics of Papua Barat Province.

BPS-Statistics of Papua Barat Province. (2016a). Air traffic Papua Barat, 2003-2014. https://papuabarat.bps.go.id/statictable/2015/03/06/50/lalu-lintas-penerbanganpapua-barat-2003-2014.html

BPS-Statistics of Papua Barat Province. (2016b). Total of disembarkation and embarkation passenger of domestic voyage at 3 ports in Papua Barat, 2005-2014. https://papuabarat.bps.go.id/statictable/2015/03/06/51/total-keberangkatan-dankedatangan-penumpang-dari-pelayaran-dalam-negeri-di-3-pelabuhan-yangdiusahakan-di-papua-barat-2005-2014.html

BPS-Statistics of Papua Barat Province. (2015). Tabel input output provinsi Papua Barat 2013. Manokwari: BPS-Statistics of Papua Barat Province.

BPS-Statistics of Papua Barat Province. (2013). Direktori hotel dan akomodasi lainnya Provinsi Papua Barat 2013. Manokwari: BPS-Statistics of Papua Barat Province.

Camara-Leret, R., Schuiteman, A., Utteridge, T., Bramley, G., Deverell, R., Fisher, L.A., McLeod, J., Hannah, L., Roehrdanz, P., Laman, T., Scholes, E., et al. (2019). The Manokwari Declaration: Challenges ahead in conserving $70 \%$ of Tanah Papua's forests. Forest and Society, 3(1), 148-151. https://doi.org/10.24259/fs.v3i1.6067

CartoGIS Services, College of Asia and the Pacific, The Australian National University. (2019). West Papua base. ANU College of Asia \& the Pacific: Maps Online. Retrieved October 28, 2019. https://asiapacific.anu.edu.au/mapsonline/basemaps/west-papua-base

Chen, P.-T., \& Var, T. (2010). Distribution of tourism economic impacts: A longitudinal study. International Journal of Tourism Policy, 3(2), 91-112. https://doi.org/10.1504/ijtp.2010.034206

Conservation International. (n.d.). Bird's Head Seascape. http://www.conservation.org/places/birds-head-seascape 
Croes, R., \& Rivera, M.A. (2017). Tourism's potential to benefit the poor: A social accounting matrix model applied to Ecuador. Tourism Economics, 23(1), 29-48. https://doi.org/10.5367/te.2015.0495

Elson, D., Latumahina, M., \& Wells, A. (2016). Redefining conservation: How communities in Raja Ampat are shaping their world, and what their experience teaches us about empowerment. Singapore: Seventythree.

Fletcher, J. E. (1989). Input output analysis and tourism impact studies. Annals of Tourism Research, 16, 514-529. https://doi.org/10.1016/0160-7383(89)90006-6

Gietzelt, D. (1989). The Indonesianization of West Papua. Oceania, 59(3), 201-221. https://doi.org/10.1002/j.1834-4461.1989.tb02322.x

Hampton, M.P., Jeyacheya, J., \& Long, P.H. (2018). Can tourism promote inclusive growth? Supply chains, ownership and employment in Ha Long Bay, Vietnam. The Journal of Development Studies, $\quad 54(2), \quad 359-376$. https://doi.org/10.1080/00220388.2017.1296572

Kakazu, H. (2011). Challenges and opportunities for Japan's remote islands. Eurasia Border Review, 2(1), 1-16.

Kakazu, H. (2008). Social carrying capacity for sustainable island tourism: The case of Okinawa. The Journal of Island Studies, 7, 53-88. https://doi.org/10.1079/9781845936792.0171

Khan, H., Phang, S.-Y., \& Toh, R.S. (1995). The multiplier effect: Singapore's hospitality industry. Cornell Hotel and Restaurant Administration Quarterly, 36(1), 64-69. https://doi.org/10.1177/001088049503600121

Khan, H., Seng, C.F., \& Cheong, W.K. (1990). Tourism multiplier effects on Singapore. Annals of Tourism Research, 17(3), 408-418. https://doi.org/10.1016/01607383(90)90006-d

Kim, H., \& Kim, B.-G. (2015). Economic impacts of the hotel industry: An input-output analysis. Tourism Review, 70(2), 132-149. https://doi.org/10.1108/tr-11-2014-0056

Klijs, J., \& Marts, D.K. (2012). Manual for economic impact studies in tourism, using an input-output model. Breda, NL: NHTV Breda University of Applied Sciences.

Leunufna, S., \& Evans, M. (2014). Ensuring food security in the small islands of Maluku: A community genebank approach. Journal of Marine and Island Cultures, 3(2), 125-133. https://doi.org/10.1016/j.imic.2014.11.001

Liu, J., \& Var, T. (1982). Differential multipliers for the accommodation sector. Tourism Management, 3(3), 177-187.

Lonely Planet. (2018). Top 10 islands for 2018. https://www.lonelyplanet.com/campaign/island-guide-2018/top-10-islands-for$\underline{\underline{2018}}$

Miller, R.E., \& Blair, P.D. (2009). Input-output analysis: Foundations and extensions (2nd ed.). New York: Cambridge University Press.

Milne, S.S. (1987). Differential multipliers. Annals of Tourism Research, 14(4), 499-515.

Ministry of Tourism and Creative Economy Republic of Indonesia. (2013a). Statistik profil wisatawan mancanegara 2013. Jakarta: Ministry of Tourism and Creative Economy Republic of Indonesia. 
Ministry of Tourism and Creative Economy Republic of Indonesia. (2013b). Statistik profil wisatawan nusantara 2013. Jakarta: Ministry of Tourism and Creative Economy Republic of Indonesia.

Ministry of Tourism Republic of Indonesia \& BPS-Statistics Indonesia. (2018). Cakupan aktivitas pariwisata dalam klasifikasi baku lapangan usaha Indonesia (KBLI) 2015. Jakarta: Ministry of Tourism Republic of Indonesia.

Mollet, J.A. (2011). The dynamics of contemporary local-government policies and economic development in West Papua. Development in Practice, 21(2), 232-243. https://doi.org/10.1080/09614524.2011.543273

Polo, C., \& Valle, E. (2008). An assessment of the impact of tourism in the Balearic Islands. Tourism Economics, 14(3), 615-630. https://doi.org/10.5367/000000008785633604

Polo, C., Ramos, V., Rey-Maqueira, J., Tugores, M., \& Valle, E. (2008). The potential effects of a change in the distribution of tourism expenditure on employment. Tourism Economics, 14(4), 709-725. https://doi.org/10.5367/000000008786440210

Pratt, S. (2015). The economic impact of tourism in SIDS. Annals of Tourism Research, 52, 148-160. https://doi.org/10.1016/j.annals.2015.03.005

Pratt, S. (2011). Economic linkages and impacts across the TALC. Annals of Tourism Research, 38(2), 630-650. https://doi.org/10.1016/j.annals.2010.11.014

Pratt, S., Suntikul, W., \& Dorji, U. (2018). Economic sustainability? Examining the linkages and leakages between agriculture and hotels in Bhutan. International Journal of Tourism Research, 20(5), 1-11. https://doi.org/10.1002/jtr.2211

Raja Ampat Homestay Association. (n.d.). The Raja Ampat Homestay Association. Retrieved March 17, 2020. https://www.stayrajaampat.com/ultimate-raja-ampatguide/news/raja-ampat-homestay-association

Remi, S.S., Waluyo, S.D., \& Muljarijadi, B. (2017). The role of tourism in the development of regional economy: Case study of the special capital region of Jakarta province. AFEBI Economic and Finance Review (AEFR), 2(1), 27-42. https://doi.org/10.47312/aefr.v2i01.49

Seventythree Pte Ltd. (2019). Raja Ampat Homestay Association survey. Singapore: Seventythree.

Steenge, A.E., \& van de Steeg, A.M. (2010). Tourism multipliers for a small Caribbean island state: The case of Aruba. Economic System Research, 22(4), 359-384. https://doi.org/10.1080/09535314.2010.526926

Suryawardani, I.G.A.O., Bendesa, I.K.G., Antara, M., Nursetyohadi, D., \& Wiranatha, A.S. (2016). Implementation of social accounting matrix in calculating tourism leakage of accommodation in Bali. International Journal of Applied Business and Economic Research (IJABER), 14(13), 9377-9405. https://doi.org/10.5614/ajht.2014.13.1.01

UNEP. (1998). Island Directory. http://islands.unep.ch/Tiarea.htm

Wiranatha, A.S., Antara, M., \& Suryawardani, I.G.A.O. (2017). Impact of tourism leakage on the growth of economic sectors, employment and income distribution in Bali, Indonesia. International Journal of Economic Research, 14(8), 11-27. 
Oscar Tiku \& Tetsuo Shimizu 